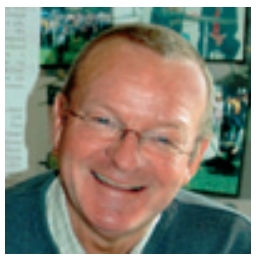

\title{
Våre sanne muligheters land
}

\begin{abstract}
Hvem trenger mest hjelp for
å unnslippe rusmisbrukets konse-

kvenser i 2010? Er det de utslitte

og utslåtte rusmisbrukerne? Er det

barna som blir uskyldige ofre for

andres rus? Eller er det leger og

hjelpeapparat som stadig opplever

at unge mennesker vi hadde mellom

hendene glipper for oss, og dør en

uverdig død i overdoselandet Norge?
\end{abstract}

Svaret er selvfølgelig at alle disse gruppene skriker etter oppmerksomhet, omsorg og forløsning - de hjelptrengende så vel som de gode hjelperne. I år som alle andre år. Overdosetallene forblir høye. Rusmisbrukere dør i behandlingskø. Foreldres rusmisbruk går i arv til barna. Alt i langt større grad enn vi kan akseptere.

Det er likevel grunn til å være forventningsfulle ved inngangen til 2010. For dem som ikke kjenner oss: Blå Kors arbeider nært sammen med norske leger og norsk helsevesen. Vi utgjør et landsomfattende nettverk som bidrar til å hjelpe rusmisbrukere og deres pårørende til et bedre liv. I dag driver Blå Kors 38 virksomheter i 14 fylker. Over 1000 mennesker har sitt daglige arbeid i organisasjonen, med tiltak som omfatter avrusning, rehabilitering, boliger med omsorgstilbud, opptrening og attføring, krisesentre og videregående skoler.

For den som følger norske medier ved inngangen til 2010, kan det se ut som norsk ruspolitikk skal føres et langt skritt videre med forskrivning av heroin. Vi kan forstå medienes reaksjon når en statsråd åpent vurderer å bli heroinlanger. Vi kan forstå en statsråd som tar et oppsiktsvekkende initiativ i en hengemyr av helsepolitiske reali- teter. Men vi i Blå Kors opplever debatten om heroinstøttet behandling som et smalt og kronglete sidespor. Det mest oppløftende ved heroindebatten er at den gir verdifull oppmerksomhet til brukergrupper og pårørende som sårt trenger det.

Det gleder et Blå Kors-hjerte, og formodentlig et stort antall norske legehjerter, at helseministerens parti har tatt et bredere initiativ. Det er hevet over tvil at Norge trenger en ruspolitisk rundvask, og at en tilnærming til hele pasienten og hele behandlingskjeden er vesentlig. Et av forslagene som skal behandles på Arbeiderpartiets landsmøte i april, er at rusavhengige skal rett til oppfølging fra første dag, og at det skal opprettes rusakutter i alle de store byene. Denne debatten bør alle partier henge seg på.

Det norske folk er sultefôret på ruspolitisk fremgang. Da Blå Kors i fjor spurte 4000 nordmenn om utviklingen i Norge de siste ti år, svarte et stort flertall at de opplever økende skadevirkninger både av alkohol og av narkotika. Om norske borgere fikk være helseminister for en dag, ville uventet mange prioritere arbeid med narkotika på topp (67\%) sammen med alkohol $(46 \%)$, helt klart fremfor aktuelle satsinger mot mangel på fysisk aktivitet $(37 \%)$ usunt kosthold (27\%), og røyking (18\%). Vi vil ikke fornærme norske leger ved å sette vesentlige helseområder opp mot hverandre, vårt poeng er at ruspolitikkens plass på de folkevalgtes agenda er langt lenger ned på listen enn folket krever.

Det norske folks engasjement kom også til syne da Blå Kors mottok til sammen 192 millioner kroner i NRKs TV-aksjon i 2008. I disse dager brukes pengene til å starte nye tiltak for barn og unge både i norske byer og i Blå Kors’ internasjonale virksomheter i India, Brasil, Ukraina og Lesotho. Respon- sen var enorm da NRK og andre medier viste reportasjer som ga oss innsyn i livet til norske og utenlandske barn som får oppveksten preget av foreldrenes rusmisbruk. På tross av taushetsplikten og skadepotensialet ved eksponering har både helsevesenet og vi andre som virker på rusfeltet, et enormt ansvar for å synliggjøre disse barna, og motvirke tabuiseringen av rusmisbrukets ofre.

De politiske initiativene ved inngangen til 2010, og den folkelige oppslutningen om en vitalisert ruspolitikk, er løfterike signaler. Mest gledelig er det likevel at nøkkelen til suksess i all hovedsak er kjent. Både Blå Kors og norske leger i sin alminnelighet vet at vi hver eneste dag lykkes med behandling, at selv tunge rusmisbrukere kommer seg løs når tiltak tilpasses den enkelte, og når behandlingskjeden ikke bryter sammen. Norges helsepolitiske utfordring er å ta vår egen medisin, slik at vi lykkes oftere.

Man kan stirre seg blind på rusfeltets tilsynelatende stagnasjon og svingdørsproblemer, enten man ser på systemsvikt i omsorgsapparatet, eller man ser ansiktet til en tilbakevendende pasient på legekontoret. Derfor mitt valg av tittel, som henspiller på Piet Heins trosbekjennelse. Den begynner slik: «Jeg tror at tro på egne grenser røver oss våre sanne muligheters land.»

Alle vi som arbeider med mennesker i vanskelige livssituasjoner, har et stort ansvar selv om de samme utfordringene møter oss igjen og igjen. Det påhviler oss ufortrødent å gripe de muligheter vi har. La meg også minne om Piet Heins konklusjon: «Det er utrolig hva man ikke kan når man av ærlig vilje ikke prøver.»

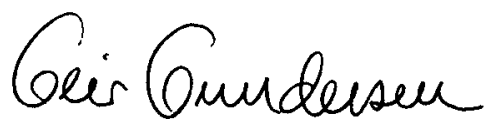

I neste nummer:
Metanolforgiftning

Tvangsinnleggelse

Leger på legevakt
Nøytropen enterokolitt

Infeksiøs endokarditt

Utplassering av hjertestartere 